\title{
SARCASM AND THE TRANSLATION QUALITY IN THE SUBTLE ART OF NOT GIVING A FUCK BOOK
}

\author{
Moh. Zawawi, Devi Laila Maghfiroh
}

\author{
zawawi@bsa.uin-malang.ac.id \\ Universitas Islam Negeri Maulana Malik Ibrahim \\ Malang, East Java, Indonesia
}

\begin{abstract}
Sarcasm is a harsher style of satire in hurtful jokes with a specific purpose. Sarcasm is the dominant language style used in Mark Manson's The Subtle Art of Not Giving A Fuck. This study aims to identify sentence forms of sarcasm and analyze the translation quality of sarcastic expressions. This translation study employs a qualitative descriptive design. The research data takes the form of sentences containing sarcasm and its translation. The data is collected through document analysis, interviews, and focus group discussions. The results showed four types of sarcasm in the book The Subtle Art of Not Giving A Fuck, including ridicule, satire, proximity, and humor. Besides, the translation quality of the book The Subtle Art of Not Giving A Fuck has a high level of accuracy, acceptability, and readability, evidenced by the proper use of eleven translation techniques applied by the translator to 145 data. The frequent techniques contributing to the quality of translation are compensation, adaptation, transposition, and modulation techniques.
\end{abstract}

Keywords: translation quality, sarcasm, translation techniques

\section{INTRODUCTION}

Sarcasm is the harshest satire style, which is bound to the context and culture. The expression of sarcasm in one culture may be deemed a natural expression by people of different cultures. Sarcasm may consist of cynicism, irony, or satire. It is at a higher level than cynicism, irony, and satire. Sarcasm may aim to mock, criticize, insinuate as an expression of proximity and humor (Aflikhah, 2012, p. 3-6). Thus, insights into the community's culture are needed, particularly for translators, before dealing with sarcasm in the texts.

Translation requires a translator to convey messages from the author's source language to the readers' target language by maintaining its language style. Nida \& Taber (1982) stated that translating produces equivalence in the aspects of messages and language style. Therefore, the application of the proper technique is indispensable to achieve quality in translation. According to Dhyaningrum et al. (2016, p. 212), translation techniques are procedures for diverting messages from the source language into the target language that helps translators determine the correct equivalent in the structure and form of words, phrases, clauses, and sentences. According to Molina and Albir (cited in Mardiana, 2014, p. 121), translation techniques are procedures for classifying and analyzing equivalence to achieve good quality translations. Kardimin (2017, p. 188) emphasized that, in assessing the translation quality, the three aspects of accuracy, acceptability, and readability must be taken into consideration.

Moreover, each text or book has its peculiarities and interests for readers, including its language style. The author's message must be conveyed to the reader. For this reason, it calls for attention to the author's language style, namely by observing and examining the use of language styles in the author's work (Wuryantoro, 2018, p. 12) sharply. For instance, the sarcasm translation must maintain the sarcasm and its cultural 
aspects from the source language into the target language. The sarcasm in the source language with a different cultural background could differ from the sarcasm in the target language. Also, the sarcasm language style's effect in the source language must be felt by the reader of the target language. For this particular practical reason, we carried out a translation study on the popular book The Subtle Art of Not Giving A Fuck.

In 2018, the book became a best-selling book, which is the first work of Mark Manson, a well-known blogger in New York. This book is top-rated and receives significant readership around the world. It contains intelligent and innovative advice to live life in the style of sarcasm. The author's sarcasm is spelled in this book. Therefore, it is worth investigating how the translator can maintain a sarcasm style in the target language with the same effect as the reader in the source language.

There have been some previous studies regarding sarcasm and its translation quality. Anggraini et al. (2020) analyzed translation techniques in translating sarcasm expressions and their impact on the translation quality in terms of accuracy. They found that established equivalent is most frequently applied in dealing with sarcasm expressions and making the translation accurate. Sukmaningrum (2016) investigated the translation techniques used in translating the irony and sarcasm utterances in a novel. She revealed that sarcastic expressions in the novel are translated by applying reduction, amplification (addition), compensation, transposition, adaptation, discursive creation, and calque techniques. Arunsamrana \& Tungtang (2015) examined linguistic and cultural barriers to English-Thai translation of sarcasm in The Big Bang Theory movie. They discovered that linguistic barriers to sarcasm translation include syntactic, lexical, and semantic aspects, while the cultural barriers were based on intercultural barriers, namely culture-specific expressions and allusions. Some other studies on the application of translation techniques such as in the news articles (Junining \& Kusuma, 2020), the shift transitivity system in the presidential inaugural speeches (Hidayat, 2018), and the form and meaning of conjunctive relation and it is translated from the source language into the target language (Sriyono, 2011).
From the previous research above, the authors found similaritiesand differences with the present study. The similarities and differences lie in the theme, approach, or object being studied. Therefore, the authors focus on the types of sarcasm, the application of translation techniques, and its consequence to the translation's accuracy.

\section{Sarcasm}

A term's meaning will undoubtedly continue to develop over time in all its aspects, including language development, such as the meaning shift. The meaning of the sarcastic term also develops along with the development of language and the language's function. Sarcasm cannot be separated from the community's culture, and it tends to differ between one cultural background and another (Haiman, 1997, p. 16).

In the beginning, sarcasm refers to harsh words aimed at mocking or criticizing (Wicaksono, 2014, p. 44). According to Keraf (2007, p. 143), sarcasm is an expression that is harsher than irony with full of bitterness and ridicule. Sarcasm is a satirical style of language that contains jokes, ridicule, and harsh criticism, such as You bastard! (Hidayah, 2016, p. 140). It illustrates that sarcasm at the beginning of its development meant stiffness and limited to the spelling out harsh words to mock and hurt.

Furthermore, the meaning of sarcasm extends not only covers hurtful ridicule and harsh words, but it also includes many purposes in various contexts. Sarcasm is a way for someone to mean something implicitly (King, 2016, p. 90). Sarcasm is a rough language style used to shorten expressions with complex meanings. For example, the refusal with sarcastic style "Dammit!" or "Bastard!", in which the speaker needless to explain the answer, as it means an entirely short form of rejection. Indeed, the predominant form of sarcasm is ridicule or anything negative, but sarcasm is often used in communication to identify a person's degree of proximity (could be as an affection or humor expression). However, improper use of humor sarcasm may cause hurt the interlocutor because it can lead to misunderstanding as a complete insult (Haiman, 1997, pp. 18-20).

Throughout its development, sarcasm is limited to the sole expression and multiple interpretations in its meaning. King (2016, pp. 
91-95) reiterates that sarcasm utterance means just the opposite of something being said. Even so, the essence of sarcasm remains above the level of satire. According to Haiman (1997), sarcasm is a style of 'pretending' or mimicry, which entails that meaning is contradictory to what one has expressed, yet its full meaning cannot be separated from the context surrounding it.

In sum, sarcasm is a harsh style in its form and meaning and is bound to the context. Besides, it may be aimed at various purposes, such as to ridicule, criticize, show proximity, and express a joke. It can be divided into several forms according to goals or purposes subject to context and culture. The forms of sarcasm are as follows:

1. Mockery or ridicule

This type's sarcasm takes the form of ridicule or bitter words spoken directly (Wicaksono, 2014, p. 44). For example: "You are shrimp-brained! stupid!".

2. Satire

It is an indirect insult or ridicule; the meaning of sarcasm is inversely proportional to what is said (King, 2016, pp. 90-94). Example: "It is so good for you to stay here (for this long); it is completely free".

\section{The expression of proximity}

Sarcasm can also show how close a person is. It is commonly seen in male friendships. They often use a unique address or nickname in a sarcastic manner (Haiman, 1997, p. 16). The examples of sarcastic addressing patterns around East Java's teenaged-male are "Cok" and "des (a shortened form of bedes (a goat)).

4. Humor

Sarcasm is also often used by the comedian to create fresh material for jokes. For example: "Dasar buaya kelas cupang, dompet tipis sudah pandai mempermainkan cewek" (you are such a poor playboy, but good at playing with girls".

\section{Translation}

The translation is a transfer of meaning from the source language to the target language. Therefore, the author's message's accuracy is of importance to be conveyed to the reader (Wuryantoro, 2018:16-17). Translating is rewriting the author's ideas in the target language, including the language style and way of presenting the author's ideas. Translating is not only writing down ideas or combining the results of one's thoughts but re-expressing the message of work by paying attention to the details and trying to maintain the language style (Fatawi, 2013: 9). Each book has its language style in expressing the author's ideas or topics of particular interest to readers.

For this reason, a concrete explanation is needed by paying attention to the author's language style, namely by observing and examining the use of language styles in his or her work sharply. Maintaining the meaning of the author's style is a significant mandate for translators. They must have a broad knowledge of variations in language styles from various cultures so that the meaning of the source language can be accepted with the equivalent meaning by the target language readers (Wuryantoro, 2018, p. 12).

The essence of translation quality is achieving meaningfulness by maintaining the author's language style through the proper application of translation techniques (Fatawi, 2013, p. 33). Therefore, a translator must be wise in selecting the translation techniques as they will affect the translation quality, namely on the aspects of accuracy, acceptability, and readability. Molina and Albir (as cited in Wuryantoro, 2019, p. 83; Fawcett, 2003, pp. 37-38), there are 18 types of techniques in translating, including: adaptation; amplification; borrowing; calque; compensation; description; addition; equivalents; generalization; linguistic amplification; linguistic compression; literal translation; modulation; particularization; reduction; substitution; transposition; and variations.

\section{Translation Quality}

The ultimate goal of translating is to achieve a quality translation. It also aims to reduce the deficiencies in translation as an evaluation to get the best translation strategies (Kardimin, 2013, p. 419). The accuracy of translation is the equivalent of the source language text to the target language, the equivalent of meaning, message, and purpose of the source language to the target language. Accuracy is at the level of words, phrases, or sentences and the level of text. Besides, the accuracy involves the linguistic, semantic, and pragmatic aspects of the text. Acceptability 
refers to the conformity with the linguistic and textual norms of the target language. The acceptability considers the cultural aspect of translation based on the target language norms. The readability concerns the ease with which the reader understands the translated text (Fahrurrozi \& Wicaksono, 2016, p. 351).

\section{Method}

This study uses a descriptive qualitative method that relies on the translated text as data (Raco, 2013, pp. 61-64). This research's object is the sarcasm language style contained in the translation book The Subtle Art of Not Giving a Fuck by Mark Manson. Due to the time constraints, this research is limited to chapters 1 and 2, which are considered capable of representing all the book's data.

In this study, there are primary data and secondary data. This study's primary data were every sentence containing the sarcasm language style in the book and its translation. The secondary data support sentences as an interpretation of the sarcasm style sentence in the book, the results of interviews, and supporting references such as books on sarcasm in English and Indonesian socioculture.

Data collection techniques used document analysis techniques, interview techniques, and focus group discussions. Document analysis techniques consist of reading and note-taking techniques. An intensive reading of the book carried out the reading technique in this study to obtain detailed and precise information (Kusmayadi et al., 2008, p. 17). The note-taking technique is employed in conjunction with the reading technique to note essential things obtained while reading. The interview technique is a data collection technique by obtaining information through question and answer with the informants (Fatta, 2007, p. 69). This study's interview technique was conducted on seven random sampling sources, namely seven readers of the book. This study's focus group discussions were conducted with translation lecturers at UIN Malang's Arabic Language and Literature (ALL) study program.

The data was analyzed through Miles \& Huberman's (2002) theory, namely data reduction, data display, and conclusion. Data reduction is a process of selecting and focusing data. The authors reduce data to classify forms of sarcasm and translation techniques. Then, the results of the data are presented in the tables and explained descriptively.

\section{Finding and Discussion}

\section{Types of Sarcasm}

After analyzing the book The Subtle Art of Not Giving a Fuck, the authors some types of sarcasm. The findings suggest that the dominant form of sarcasm is the proximity marker. Table 1 below illustrates the types of sarcasm found in the data:

\begin{tabular}{llll}
\multicolumn{3}{l}{ Table 1. Types of Sarcasm } \\
\hline Style & Type & $\boldsymbol{\Sigma}$ & $\mathbf{0}$ \\
\hline Sarcasm & Mockery/ridicul & 15 & $10,34 \%$ \\
& e & & \\
& Satire & 6 & $4,14 \%$ \\
& Proximity & 118 & $81,38 \%$ \\
Total & Humor & 6 & $4,14 \%$ \\
\hline
\end{tabular}

\section{Ridicule}

The authors found 15 mockery sarcasm data from 145 total sarcasm data. The examples are illustrated as follows:

His work was horrible, they said. Crude. Disgusting. Depraved (Manson, 2018, p. 6) (Tulisannya sangat hancur, kata mereka. Kasar. Menjijikkan. Tidak bermoral) (Manson, 2018, p. 1),

No screw that! (Manson, 2018, p. 12) (Dasar keparat kurang ajar!) (Manson, 2018, p. 17).

The excerpt above indicates the instances of utterances containing ridicule or mockery, such as horrible, disgusting, and depraved. These words are uttered as a direct sarcasm in which the explicit meaning is harsh and hurts the listener or can simply be understood. From the overall data, it can be concluded that the expression of sarcasm language style in the form of ridicule is expressed explicitly and dominantly as an outburst of anger expressions (i.e., cursing and releasing all irritation) directly without refining the speech.

\section{Satire}

The authors found six satire sarcasm. The examples are illustrated as follows:

Because once you become comfortable with all the shit that life throws at you (and it will throw a lot of shit, trustme) (Manson, 2018, 
p. 14) (karena begitu Anda nyaman dengan semua tahi yang dilemparkan oleh kehidupan pada Anda, (percayalah. Akan ada sangat banyak)) (Manson, 2018, p. 24).

In the speech, it appears that there is an implicit utterance that contains satire with the application of the sarcasm language style. The utterance was expressed implicitly. Satire's meaning means that one should not be uncomfortable with all the shit in life throws up. Based on the supporting sentence, the meaning of shit (tahi) is a life suffering that you keep trying to avoid, even though it is improbable.

\section{Proximity}

Sarcasm in the form of showing proximity is found in 118 occurrences in the data. The example is well illustrated in the below excerpt:

\begin{abstract}
In my live, I have given a fuck about many things (Manson, 2018, p. 10) (dulunya, dalam hidup saya, saya peduli akan banyak hal (Manson, 2018, p. 13) I have no fucking clue (Manson, 2018, p. 11) Say a tidak habis pikir (Manson, 2018, p. 16).
\end{abstract}

The utterance above contains sarcasm in the use of the word fuck, " but it aims to show the speakers' proximity. Besides, other words such as shit or suck were also found, which are normal and no longer a sarcastic word that may hurt. However, communication sarcasm can lead to misunderstandings with listeners who have different socio-cultural backgrounds with the speakers. This style's sarcasm is typically not expressed in heavy stress, high intonation, or in an unstable emotional state, but it is uttered in flat intonation and almost with no stressing.

\section{Humor}

Sarcasm is not only used to swear or express anger in specific contexts, but it can also be employed as a joke. Placing humorous sarcasm on those with the same sense of humor will receive a good response, and if it goes beyond the limits of humor, sarcasm may be considered a complete insult (King, 2016, pp. 90-91). The authors found six humor sarcasm out of 145 total sarcasm data. The examples are illustrated as follows:

If you feel like shit for even five minutes, (...) (Manson, 2018, p. 8). (jika saat ini Anda merasa seperti tahi kerbau bahkan untuk lima menit saja, (...) (Manson, 2018, p. 8)

The utterance above shows the use of a language style such as shit; even though it is a sarcastic word, using it is a joke based on the meaning of the context. The sarcasm of humor will be a joke for readers who consider the speech as a joke. Conversely, it will be regarded as a complete insult when the reader feels hurt over the word's use. Often humor sarcasm goes hand in hand with satire that still has an implied meaning in it, namely wrapping sarcasm with humorous sarcasm. Therefore, sarcasm can be classified as humor depending on how the reader receives it and the contextbound to it.

\section{The translation quality of sarcasm}

Referring to the theoretical framework mentioned above, the quality of translation is influenced by the translation techniques under operation. The following table illustrates the translation techniques applied for sarcasm utterances in the book The Subtle Art of N ot Giving a Fuck:

Table 2. Translation Techniques of Sarcasm

\begin{tabular}{lcc}
\hline Translation Techniques & $\boldsymbol{\Sigma}$ & $\mathbf{\%}$ \\
\hline Compensation & 55 & $37,93 \%$ \\
Adaptation & 27 & $18,62 \%$ \\
Modulation & 26 & $17,93 \%$ \\
Transposition & 14 & $9,65 \%$ \\
Reduction & 11 & $7,59 \%$ \\
Addition & 5 & $3,45 \%$ \\
Description & 2 & $1,38 \%$ \\
Borrowing & 2 & $1,38 \%$ \\
Equivalence & 1 & $0,69 \%$ \\
Calque & 1 & $0.69 \%$ \\
Explication & 1 & $0,69 \%$ \\
Total & $\mathbf{1 4 5}$ & $\mathbf{1 0 0} \%$ \\
\hline
\end{tabular}

The sarcasm is dominantly translated by applying the compensation technique. The compensation technique is a technique that prioritizes the delivery of the author's message to the reader with the stylistic transfer because the source language style cannot be applied in the target language (Junining, 2018, p. 78). It is also influenced by the number of sarcasm showing the proximity to convey the meaning to the reader. For examples:

No fucks given (Manson, 2018, p. 9)

Tidak masalah kan? (Manson, 2018, p. 11).

This translation identifies stylistic changes due to differences in stylistics in the 
source and target language. The translator refines the sarcasm and yet still allows the author's message to the reader.

The second most common technique is adaptation. The adaptation technique is replacing the cultural elements of the source language with the elements of the target language culture (Wuryantoro, 2018, p. 84). For examples:

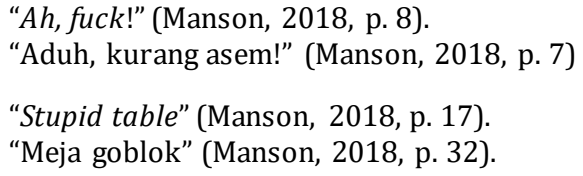

The translation has succeeded in maintaining the sarcasm style with adaptation technique to adjust to the target language culture from both examples above. The words 'kurang asem' and 'goblok' are sarcasm styles in Javanese-Indonesian. Based on the analysis, many adaptation techniques are applied to the form of sarcasm, aiming to maintain the sarcasm style in the target language. Modulation and transposition techniques are also operated because of differences in the source language's system and structureand the target language. The omission technique is also applied to minimize wordiness, including omitting unnecessary words.

Regarding the assessment of three aspects of the translation (i.e., accuracy, acceptability, and readability), the authors concluded as follows:

Table 3. The Translation Quality of Sarcasm

\begin{tabular}{cccc}
\hline Aspects & Level & $\boldsymbol{\Sigma}$ & $\mathbf{0}$ \\
\hline Accuracy & Accurate & 99 & 68,28 \\
& & & $\%$ \\
& Less Accurate & 44 & 30,34 \\
& & & $\%$ \\
& Inaccurate & 2 & $1,38 \%$ \\
Acceptability & Acceptable & 126 & 86,90 \\
& & & $\%$ \\
& Less Acceptable & 17 & 11,72 \\
& & & $\%$ \\
Readability & Unacceptable & 2 & $1,38 \%$ \\
& Easy & 134 & 92,41 \\
& & 11 & $\%$ \\
& Moderate & - & \\
& Hard & - & - \\
\hline
\end{tabular}

Based on the data above, the translation of the book The Subtle Art of Not Giving a Fuck has a high level of accuracy, acceptability, and readability. It is influenced by the translation techniques applied.
Techniques that contribute to the translation's accuracy are transposition, adaptation, compensation, familiarity, calques, and borrowing. Simultaneously, the techniques that influence low accuracy are description, reduction, addition, exploitation, and modulation.

Furthermore, the techniques that contribute to the translation's acceptability are transposition, modulation, adaptation, calquing, compensation, common equivalents, and borrowing. Meanwhile, techniques affecting the lack of acceptability are reduction, addition, and exploitation. However, the description technique is considered unacceptable by most of the interviewed informants. Besides, the technique which affects moderate readability is the reduction technique. For this case, consider the following excerpts:

"What the fuck is the point of this book anyway?" (Manson, 2018, p. 14).

"Ngomong-ngomong apa inti buku ini?" (Manson, 2018, p. 23).

The sarcasm expression of 'What the fuck' is translated by applying the reduction or omission technique. Readers view that this technique can reduce the accuracy and acceptability of the translation.

\section{Conclusion}

The authors found four types of sarcastic expressions in the book The Subtle Art of Not Giving a Fuck: ridicule, satire, proximity, and humor. There are 11 techniques for translating sarcastic utterances: transposition, adaptation, modulation, compensation, reduction, addition, equivalents, description, borrowing, calques, and explication techniques. These techniques produce quality translations that have a high degree of accuracy, acceptability, and readability. To sum up, the sarcasm-style translation is conducted by maintaining the level of sarcasm and adjusted to the culture of the target language's readers, while the translation of the sarcasm of proximity tends to be refined the delivery of the author's message to the reader. 


\section{REFERENCES}

Aflikhah, Adik Oki. (2012). “Gaya Bahasa Sarkasme dan Kekhasan Bahasa Penulis pada Judul Rubrik Kriminal di Surat Kabar Harian Meteor Edisi April 2012". Fakultas Keguruan dan Ilmu Penddidikan, Universitas Muhammadiyah Surakarta.

Anggraini, D., Nababan, M. R., \& Santosa, R. (2020). The Impact of Translation Techniques towards the Accuracy of Sarcasm Expression in Television Series the Big Bang Theory. International Journal of Multicultural and Multireligious Understanding, 7(2), 391-400.

Arunsamrana, P., \& Tungtang, P. (2015). Analyzing linguistic and cultural barriers to English -Thai translation of sarcasm in The Big Bang Theory.

Dhyaningrum, Ambhita dkk., (2016). "Analisis Teknik Penerjemahan dan Kualitas Terjemahan Kalimat yang Mengandung Ungkapan Satire dalam Novel The 100-Year-Old Man Who Climbed Out of The Window and Dissappeared" dalam Jurnal Prasasti: Journal of Linguistic, Vol. 1, No. 2, November Tahun 2016.

Fatta, Hanif Al. (2007). Analisis dan Perancangan Sistem Informasi. Yogyakarta: Andi Offset.

Fawcett, Peter. 2003. Translation and Language. Manchester: St. Jerome Publishing.

Haiman, John. (1998). Talk is Cheap. New York: Oxford University Press.

Hennink, Monique, M. (2013). Focus Group Discussion. New York: Oxford University Press.

Hidayah, Nurul. (2016). Pembelajaran Bahasa Indonesia di P erguruan Tinggi. Yogyakarta: Garudhawacana.

Hidayat, T. (2018). TRANSLATION SHIFT OF A TRANSITIVITY SYSTEM IN OBAMA AND TRUMP'S INAUGURATION SPEECH. LiNGUA: Jurnal Ilmu Bahasa dan Sastra, 13(2), 91 - 100. doi:https://doi.org/10.18860/ling.v13i2.4990

Junining, Esti. (2018). Strategi dan Kiat Praktis Penerjemahan. Malang: UB Press.

Junining, E., \& Kusuma, V. (2020). TRANSLATION STRATEGIES FOR TRANSLATING A NEWS ARTICLE. LiNGUA: Jurnal IImu Bahasa dan Sastra, 15(1), 79 - 90. doi:https://doi.org/10.18860/ling.v15i1.9562

Kardimin. (2017). “Ragam Penerjemahan” dalam Jurnal Studi Islam, Vol. 2, No. 1, Juni Tahun 2017.

Kardimin. (2013). Pintar Menerjemah: Wawasan Teoritik dan Praktek. Yogyakarta: Pustaka Pelajar

Keraf, Gorys. (2007). Diksi dan Gaya Bahasa. Jakarta: Gramedia.

King, Patrick. (2016). Laugh Tactics Think Quicklyon Your Feet. Social Interaction Socialist.

Kusmayadi, dkk. (2008). Be Smart Bahasa Indonesia. Bandung: Grafindo.

Mardiana, Wiwik. (2014). “Teknik Transposisi dan Modulasi: Kesepadanan dan Pergeseran dalam Penerjemahan Cerpen berjudul My Beloved Edith" dalam Jurnal Parole: Journal of Lingistic, Vol. 4, No. 2, Oktober Tahun 2015.

Huberman, M., \& Miles, M. B. (2002). The qualitativeresearcher's companion. Sage. 
Nida, E. A., \& Taber, C. R. (Eds.). (1982). The theory and practice of translation (Vol. 8). Brill Archive.

Raco, J.R. (2013). Metode Penelitian Kualitatif Jenis Karakteristik dan Keunggulannya. Jakarta: Grasindo.

Sriyono, S. (2011). TERJEMAHAN CONJUNCTIVE RELATION (CR) DALAM NOVEL MIXED BLESSINGS DAN NOVEL BERKAH PENUH COBAAN. LiNGUA: Jurnal Ilmu Bahasa dan Sastra, 6(1). doi:https://doi.org/10.18860/ling.v6i1.1297

Sukmaningrum, R. (2016). The Analysis of Translation Techniques of Irony and Sarcasm in Novel Entitled The Sign Of The Four. ETERNAL (English Teaching Journal), 7(1).

Tarjo. (2019). Metode Penelitian. Yogyakarta: Deepublish.

Wicaksono, Andri. (2014). Catatan Ringkas Stilistika. Yogyakarta: Garudhawacana

Wicaksono, Andri dan Fahrurrozi. (2016). Sekilas Tentang Bahasa Indonesia. Yogyakarta: Garudhawacana.

Wuryantoro, Aris. (2018). Pengantar Penerjemahan. Yogyakarta: Deepublish.

Yusuf, Muri. (2016). Metode Penelitian Kuantitatif, Kualitatif, dan Penelitian Gabungan. Malang: Kencana 